\title{
9 - Experimental model of induction of diabetes mellitus in rats ${ }^{1}$
}

\author{
Eliziane Nitz de Carvalho ${ }^{2}$ \\ Nestor Antônio Schmidt de Carvalho ${ }^{3}$ \\ Lydia Masako Ferreira ${ }^{4}$
}

Carvalho EN, Carvalho NAS, Ferreira LM. Expenimental model of induction of diabetes mellitus in rats. Acta Cir Bras [serial online] 2003 Vol18 Special Edition. Available on URL: http://www.scielo.br/acb.

ABSTRACT - Diabetes mellitus is a potentially morbid condition with high prevalence worldwide, thus being a major medical concem. Experimental models play an important role in understanding such a disease, which is treatable only. This study describes a rat diabetes mellitus model induced by administering a reduced dose of alloxan, thus greatly reducing the animals' death rate.

KEY WORDS - Alloxan. Diabetes. Rats.

\section{Introduction}

Due to its high prevalence and potential deleterious effects on a patient's physical and psychological state, diabetes mellitus, which can result in a morbid condition, is a major medical concern. ${ }^{1,2}$

According to the World Health Organization (WHO) the number of diabetics has doubled in the past few years and is expected to double once again by the year 2025 . Today, there are 160,000 diabetics worldwide, 10,000 in Brazil only, which makes the county the sixth in the world rank. ${ }^{3}$

In humans, diabetes mellitus is one of the most prevalent conditions with spontaneous manifestation. In animals, it can be induced by partial pancreatectomy or by the administration of diabetogenic drugs such as alloxan, streptozotocin, ditizona and anti-insulin serum. ${ }^{4}$

These agents selectively destroy the Langemans islet B-cells. The best known drug-induced diabetes model is the alloxan diabetes. Alloxan, a denivative of uric acid, as well as of other substances of different chemical groups, cases B-cells to degranulate and consequently degenerate.

Alloxan induces ineversible diabetes mellitus after 24 hours following its administration and the condition proves to be chronic by laboratory tests after seven days.

1. Plastic Surgery laboratory of Plastic Surgery Division of Federal University of São Paulo - Paulista School of Medicine (UNIFESP-EPM).

2. PhD student of Plastic Surgery Division of Federal Univensity of São Paulo - Paulista School of Medicine (UNIFESP EPM).

3. Professor of Physiology for the Odontology, Nursing and Speech Pathology courses at UNIVALI. Brazil

4. Head of Plastic Surgery Division of Surgery Department and Coordinator of Post-graduation Program in Reconstructive Plastic Surgery - UNIFESP - EPM. Brazil 
Proposition

This study describes the method of inducing diabetes mellitus in rats by alloxan administration.

\section{Method description}

The expenimental animal in this model is the male, adult Wistar EPM (Rattus norvegicus alvinus, Rodentia, Mamalia) weighing 250 to $350 \mathrm{~g}$.

After a 48-hour fast, the rats were weighed and anesthetized by her inhalation in a glass dome. A solution of alloxan at $2 \%$ diluted in saline at $0.9 \%$ was administered to the animals in a single dose comesponding to $40 \mathrm{mg}$ of alloxan per $\mathrm{kg}$ of animal weight injected into their penial vein.

Food and water were presented to the animals only 30 minutes after the dnug administration.

From the animals subjected to this procedure, $40 \%$ developed chronic diabetes mellitus; $20 \%$ either developed the condition to a mild or slight degree or did not developed it at all; and the remaining $40 \%$ died within the first seek of follow up, probably due to acidosis.

The animals showed the following signs of the condition: polydipsia (abnormal thirst), polyuria (increased urine volume), weight loss (due to lean mass loss), asthenia (weakness due to the inability to use glucose as a source of energy), dehydration (due to the animal body's attempt to get rid of the excess blood glucose as the normal process of storing glucose in the body cells is impaired).

In order to assess the effect of alloxan and to chemically establish the diabetic condition, an incision was done in any of the four veins in the tail of the rat using a 15 scalpel blade 10 days after induction. A sample of the rat's venous blood was collected on a reagent strip 10 days after the diabetes induction procedure for blood glucose level detemination using a portable glucose analyzer.

The level of serum glucose considered to be normal in rattus novergicus ranges from 50 to 135 $\mathrm{mg} / 100 \mathrm{ml} .{ }^{14}$ In this study, rats with glucose levels above $200 \mathrm{mg} / \mathrm{dl}$ were considered as having severe diabetes.

\section{Procedure for alloxan induction of diabetes mellitus}

Lying on its back, the animal is given an injection of alloxan in its penial vein (Figure 1).

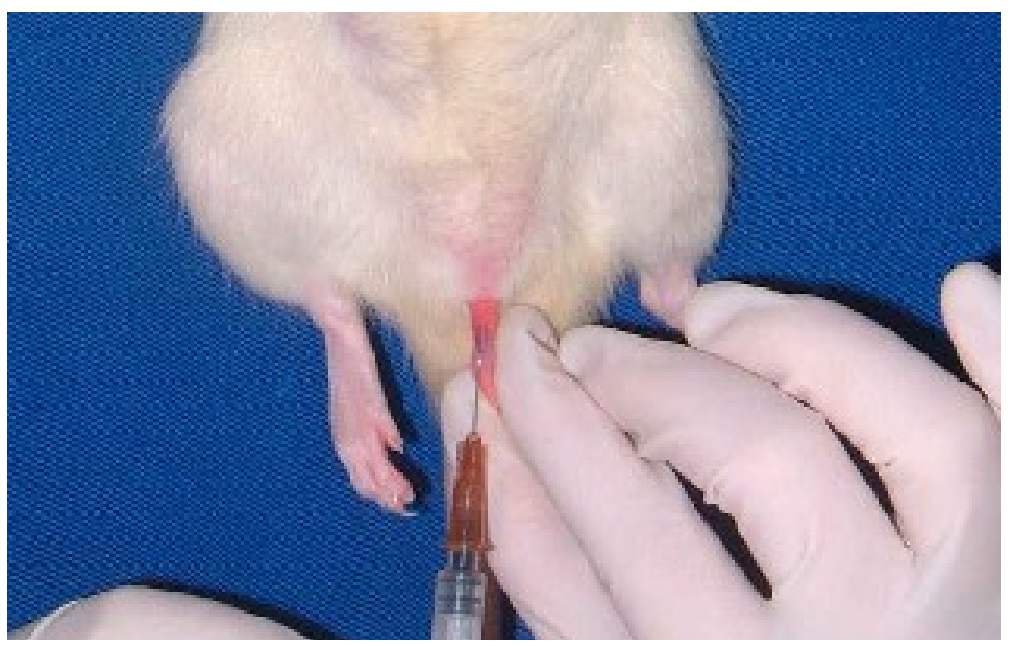

FIGURE 1 - Administration of alloxan in the animal's penial vein. 
Incision in a tail vein for determination of glycemia level 10 days after alloxan injection (Figure 2).

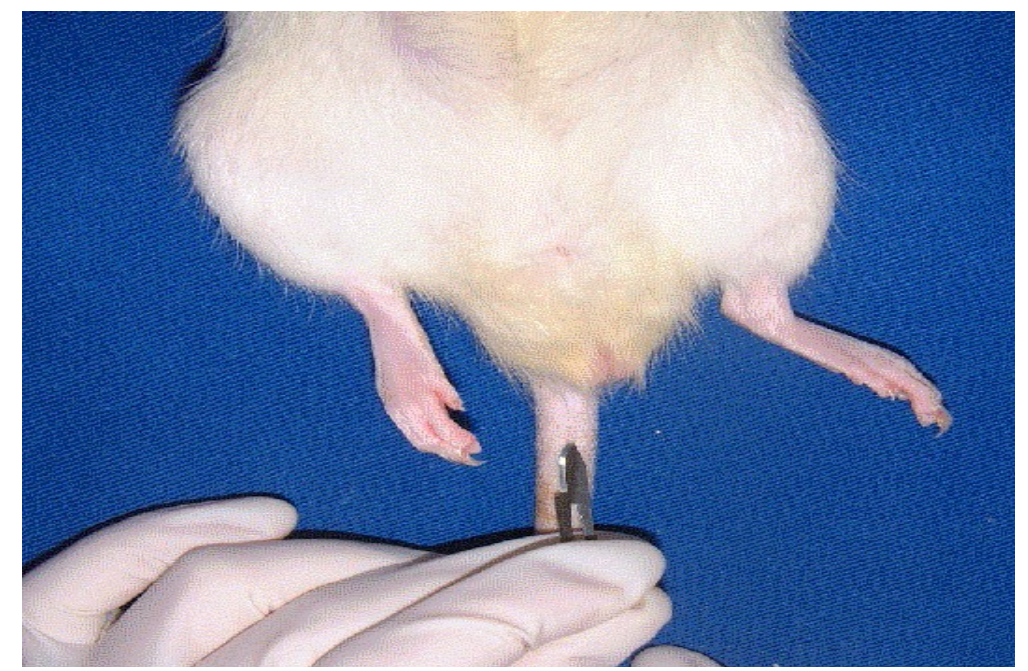

FIGURE 2 - Incision in a tail vein of the rat with a 15 scalpel blade.

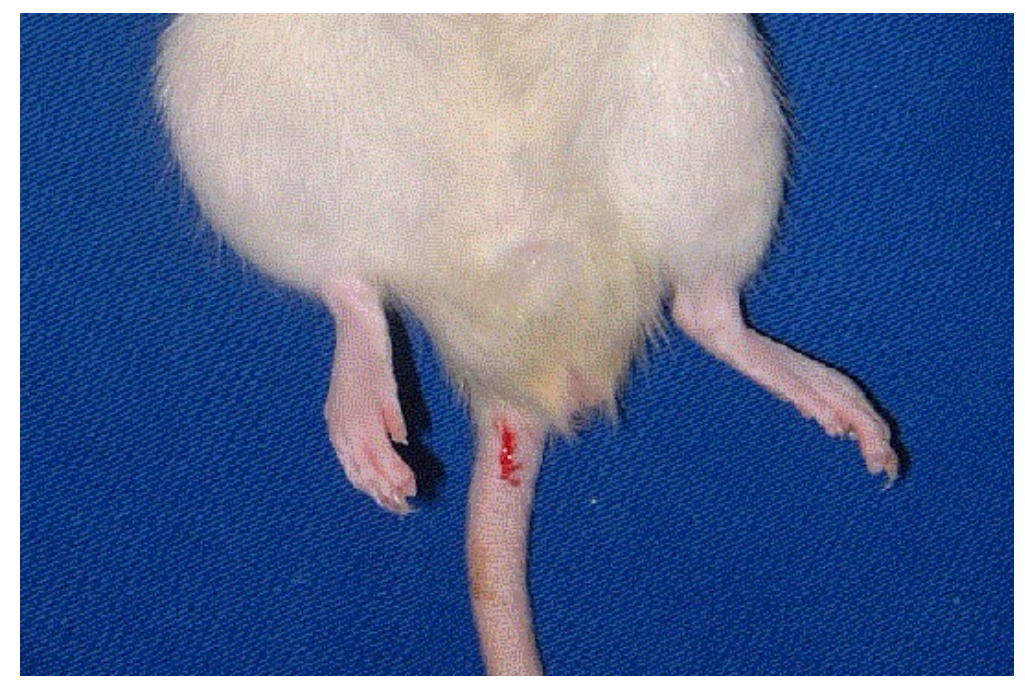

FIGURE 3 - Bleeding resulted from the tail vein incision. 


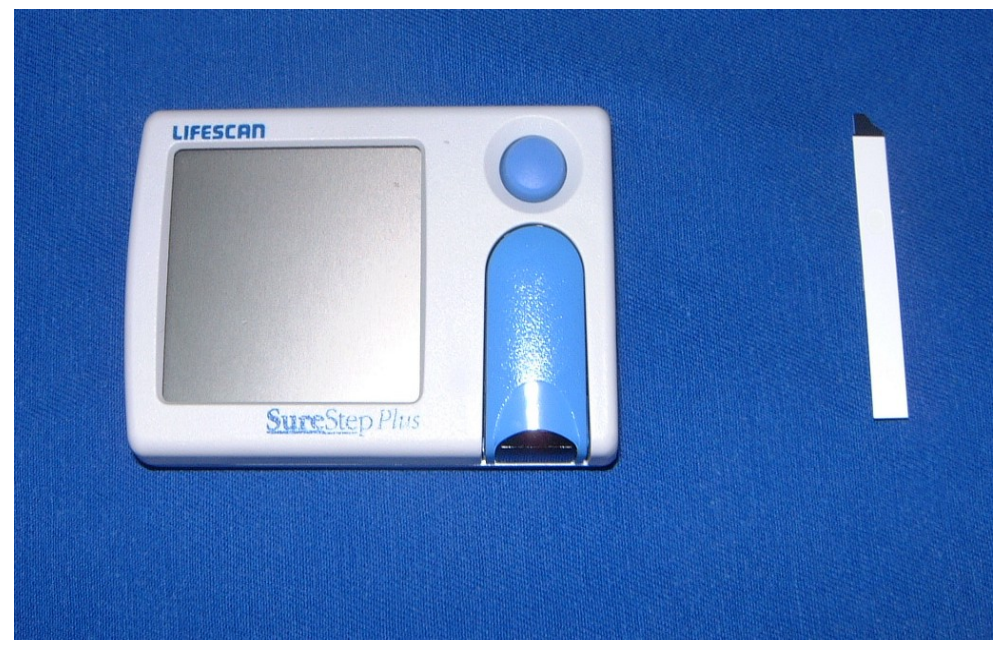

FIGURE 4 - Portable blood glucose test device.

Perspectives

The procedure for chemical induction of diabetes mellitus proved to be effective. This experimental model adds to various others and can be used as altemative model in studies carried out in several fields such as plastic surgery.

\section{References}

1. Macedo CS, Capelletti SM, Mercadante MCS, Padovani CR, Spadella CT. Role of metabolic control on diabetic nephorathy. Acta Cir Bras 2002;17 (6): 370-5.

2. Halpem A, Mancini MC, Mancini MMAM. Diabetes mellitus. Rev Bras Med 2000:57.

3. Beretta ALRZ. Campanha de prevenção e diagnóstico do diabetes realizada pela UNIARARAS e prefeitura municipal na cidade de Araras. Laes \& Haes 2001; 22(131): 188-200.

4. Cistemas JR. Fisiologia das ilhotas de Langenhans. In: Douglas CR. Tratado de fisiologia aplicada a ciências da saúde. $4^{\text {th }}$ ed. São Paulo:Robe; 2000. p. 1073-86.

5. Ahrén R, Sundkvist G. Long Term Effects of Aloxan in Mice. Int J Pancreatol. 1995;2:197-201.

6. Bhattacharya SK. Activity of shilajit on aloxan induced hypoglicaemia in rats. Fitoterapia 1995;116(4):32832.

7. Calza KC, Marqueti RC, Silveira MPM. Efeito cicatrizante do laser HeNe atuando na cicatrização de tecidos cutâneos em ratos (aloxânicos) diabéticos e normais. Rev Bras Fisioter, 2001; Suppl:28.

8. Covington DS, Xue H, Pizzini R, Lally K, Andrassy RJ. Streptozotocin and aloxan are comparable agents in the diabetic model of impaired wound healing. Diabetic Res 1993;23: 47-53.

9. Dunn JS, Mcletchie NGB.Experimental alloxan diabetes in the rat. Lancet 1943; 245: 484-7.

10. Godoy P, Barreto Neto M.. Pâncreas endócrino. In: Bogliolo L. Patologia $3^{\text {rd }}$ ed. Rio de Janeiro: Guanabara Koogan; 1981. p.1056-60.

11. Machado JLM, Macedo AR, Silva MD, Spadella CT, Montenegro MRG. Caracterização de um modelo experimental de neuropatia em ratos diabéticos induzidos pela aloxana. Acta Cir Bras 2000; 15 (2): $86-93$. 
12. Oi K, Komori H, Kajimura H. Changes in plasma glucose, insulin, glucagon, cathecolmine, and glicogen contentes in tissue during development of alloxan diabetes in rats. Biochem Mol Med 1997; 62: 70-5.

13. Spadella CT, Bacchi CE, Mercadante MCS, Machado JLM, Schellini AS. Tratamento convencional com insulina versus lesões renais no rato diabético aloxânico. Acta Cir Bras 1995; supl. 2: 103.

14. Harkness JE, Wagner JE. Biologia e clínica de coelhos e roedores. $3^{\text {rd }}$ ed. São Paulo: Roca; 1993. p.48-55.

Carvalho EN, Carvalho NAS, Ferreira LM. Modelo experimental de indução do diabetes mellitus em ratos. Acta Cir Bras [serial online] 2003 Vol 18 Edição Especial. Disponível em URL: http:// www.scielo.br/acb.

RESUMO - O diabetes mellitus é uma condição mórbida da maior importância no contexto da medicina. Este artigo decreve um dos modelos de indução do diabetes mellitus com aloxano, uma das substâncias que provocam a hiperglicemia pemanente em várias espécies. Com base na literatura, tem o intuito de estabelecer esse modelo como uma opção para investigar as complicações do diabetes mellitus e seus tratamentos. Tese, ainda, considerações sobre perspectivas de aplicações deste modelo, ainda pouco utilizado.

DESCRITORES - Aloxano. Diabetes. Ratos.

Conflict of interest: none Finantial source: CAPES

Correspondence:

Eliziane Nitz de Carvalho

UNIFESP-EPM, Plastic Surgery Division, Surgery Division

Rua Napoleão de Barros, $715,4^{\circ}$ andar

04024-900 São Paulo - SP

Tel: (11)557604118 FAX: (11) 55716579

sandra.dcir@epm.br_fisioeliziane@ yahoo.com.br

Data do recebimento: $22 / 04 / 2003$

Data da revisão: $18 / 05 / 2003$

Data da aprovação: 28/07/2003 